\title{
Biology, morphology and damage of the lesser Coconut weevil, Diocalandra frumenti (Coleoptera: Curculionidae) in southern Vietnam
}

\author{
HONG-UNG NGUYEN ${ }^{1, \bullet}$, THI-HIEN NGUYEN ${ }^{1}$, NGUYEN-QUOC-KHANH CHAU ${ }^{2}$, VAN-VANG LE ${ }^{2}$, \\ VAN-HAI TRAN ${ }^{2}$ \\ ${ }^{1}$ Department of Agriculture and Aquaculture, Tra Vinh University. No. 126, Nguyen Thien Thanh Street, Ward 5, Tra Vinh City, Viet Nam \\ Tel.: +84-94-3855692, ’email: hongungtv@ gmail.com, nghongung@tvu.edu.vn. \\ ${ }^{2}$ College of Agriculture, Can Tho University. No. 3/2 Street, Ninh Kieu District, Can Tho City, Viet Nam
}

Manuscript received: 14 July 2020. Revision accepted: 20 September 2020.

\begin{abstract}
Nguyen HU, Nguyen TH, Chau NQK, Le VV, Tran VH. 2020. Biology, morphology and damage of the lesser coconut weevil, Diocalandra frumenti (Coleoptera: Curculionidae) in southern Vietnam. Biodiversitas 21: 4686-4694. The lesser coconut weevil, Diocalandra frumenti, is an emerging pest of coconut trees in Vietnam. To help develop control options for D. frumenti, this study investigated its morphological and biological characteristics, and quantified damage levels on coconut trees. Results from the study showed that attack by $D$. frumenti on coconut trees is correlated with characteristic damage symptoms (e.g., oozing sap) on all maturity stages of coconut fruits throughout the year (24.7\% infestation), with higher damage levels on young fruits (57.6\%). Results also showed that infestation levels on trees $(58.9 \%)$, coconut bunches $(19.4 \%)$, and fruits $(7.77 \%)$ varied greatly. Adults have four different morphologies, but genetic study showed that they are all one species. The life cycle from egg to adult averaged $167 \pm 34.3$ days. The average development time for eggs, larvae, female pupae, male pupae, male adults, and female adults was $5.62 \pm 0.62,142.3 \pm$ $34.3,9.79 \pm 0.86,10.2 \pm 1.26,81.5 \pm 34.7$, and $81.8 \pm 37.2$ days, respectively. In conclusion, $D$. frumenti is an important pest in coconut trees with significant fluctuations in the duration of its development stages, and variation in shape, color, and size of the eggs, larvae, pupae, and adults. They can attack any coconut orchard and have harmful impacts on coconut trees, coconut bunches, and fruits throughout the year.
\end{abstract}

Keywords: Coconut weevil, Diocalandra frumenti, genetic diversity, insect pest, Mekong Delta

\section{INTRODUCTION}

Coconut (Cocos nucifera $\mathrm{L}$ ) is a widespread tree with a total area of approximately 12 million hectares in over 89 tropical countries (Gunn et al. 2011). The plant is a source of food and raw material for consumers' products and exporting industries. It provides many products, including coconut oil, wood, and leaves (Manisha and Mandal 2011). Overall, the coconut tree has a significant role in the economy, society, and ecology of developing countries (Gunn et al. 2011).

The lesser coconut weevil, Diocalandra frumenti (Fabricius, 1801), is one of the primary pests of coconut trees in the South Pacific and many countries around the world (Given 2012). Weevil damage can cause the death of the whole host trees (Giblin-Davis 2011). D. frumenti also attacks Areca spp., nipa palm, and the other plants belonging to the Palmae family. Previously, D. frumenti was recorded to cause damages on areca, nipa palm and other plants belonging to the Palmae family in many places in the world. The European and Mediterranean Plant Protection Organization (EPPO 2012) reported that tts damages can cause fruit deformity and stunting. Larvae attack the tissues of trunks and leaves and causing gum exudation, yellowing of leaves (Vacas et al. 2017). According to Vacas et al. (2017), D. frumenti has been identified as an important pest in economically valuable palm species, including Date palm and Canary palm.

In Vietnam, coconut is an important tree that provides significant income for farmers in the Mekong Delta. However, attack by $D$. frumenti on coconut trees has been observed in recent years. The first serious D. frumenti infestation was observed in the Kien Giang province in 2012. Infected trees showed deformed shapes, reduced size of mature fruit, and dropping off of young fruits. By 2015, these symptoms occurred widely in many provinces in the Mekong Delta, and Southeast and Central areas of Vietnam. As a result, many coconut farms were destroyed and had serious problems with the productivity and quality of coconut fruits. Because coconut trees are tall, it is difficult to reach and treat $D$. frumenti infestations using chemical control methods. However, chemicals can cause environmental pollution and have harmful effects on human health (Ung 2019). Nevertheless, basic information for the management of $D$. frumenti in Vietnam is limited. Research on the biology and impact of $D$. frumenti is imperative for the development, implementation, and success of weevil control programs Therefore, the objective of this study was to quantify $D$. frumenti damage levels on coconut trees, and investigate its morphological and biological (development, fecundity, and genetic diversity) characteristics. 


\section{MATERIALS AND METHODS}

\section{Study area}

Diocalandra frumenti damage levels were surveyed from September 2015 to December 2015 on coconut orchards in three provinces (Ben Tre, Vinh Long, and Tra Vinh) in the Mekong Delta (Figure 1). Morphological and biological characteristics and living habits of $D$. frumenti were studied at laboratories of the Department of Agriculture and Aquaculture, Tra Vinh University, Vietnam and on coconut orchards in southern Vietnam from March 2016 to March 2018.

\section{Interview farmers to obtain information on lesser coconut weevil Diocalandra frumenti}

Interviewed 270 households, whose areas of at least $1,000 \mathrm{~m}^{2}$, were those involved in coconut cultivation in Ben Tre, Vinh Long and Tra Vinh provinces. The investigated contents included information on damage status and $D$. frumenti coconut orchards.

\section{Diocalandra frumenti damage levels on coconut trees}

A total of 2,700 coconut trees from 270 orchards (5-7 years) were used to investigate damage levels of $D$. frumenti on coconut orchards. Orchard farms were at least $1,000 \mathrm{~m}^{2}$. Damage was assessed by randomly selecting two coconut trees from each of five different locations within an orchard (four in the peripheral area and one in the central area), for a total of ten coconut trees per orchard. $D$. frumenti feeding damage on trees, coconut bunches, and fruits was recorded as present or absent.

\section{Morphological and biological characteristics of Diocalandra frumenti}

Studies were conducted under laboratory conditions (temperature: $28-31{ }^{\circ} \mathrm{C}$, humidity: $68-80 \%$ ). Newly oviposited eggs less than 24 hours that were oviposited on coconut tree petioles were collected to start the studies (Figure 2). Larvae and pupae were individually reared on petioles. The investigation was carried out with 120 eggs from the same location, then monitored development of these 120 eggs. Instar of $D$. frumenti larvae were determined by measuring head capsules discarded after each molt (Grunert et al. 2015). Eggs and larvae body size were also measured with the aid of a microscope.

In addition, observations on attack behavior and damage by $D$. frumenti were conduced at coconut orchards.

\section{Genetic sequence of morphology evaluation}

The sequence of the mitochondrial COI gene of the weevil morphologies were diagnosed by PCR methods according to the method described by Wibowo et al. (2015) with some modifications. This aims to evaluate their phylogenetic relationships. Denaturation happened at $94^{\circ} \mathrm{C}$ for 5 minutes in the initial stages. Then 35 cycles were denaturated at $94^{\circ} \mathrm{C}$ for 30 seconds, hardened at $45^{\circ} \mathrm{C}$ for 30 seconds, and prolonged at $72^{\circ} \mathrm{C}$ for 40 seconds. The last round was in progress in $72^{\circ} \mathrm{C}$ for $7 \mathrm{~min}$. Denaturated and electrophoresed PCR producted accord to $1.5 \%$ agarose gel in buffer TAE (1X) and deeply probed with Tanon-3500 Gel Image System.

\section{Data analysis}

Diocalandra frumenti infestation data were pooled just one year and the percentage of infested coconut orchards, trees, coconut bunches, and fruits per orchard were calculated using Microsoft Office Excel. Correlation analysis is used to determine relationship between coconut varieties and damage of $D$. frumenti.

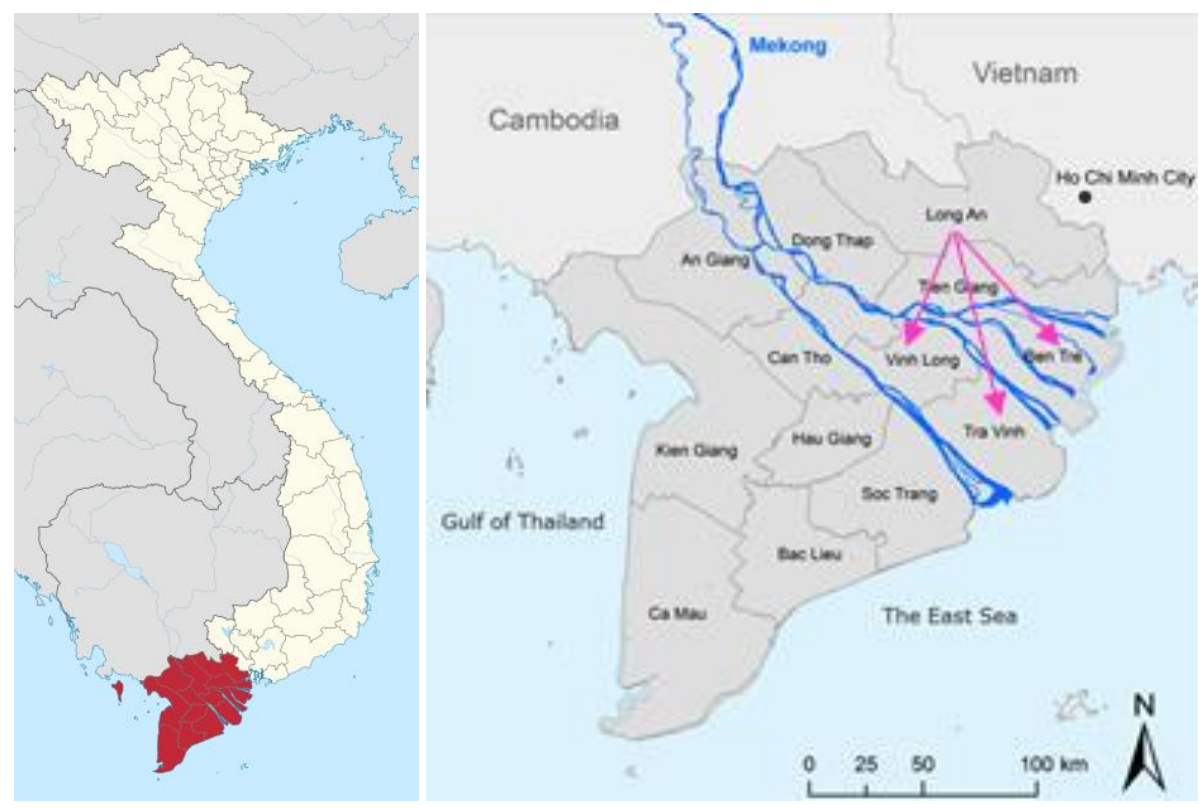

Figure 1. Map of Vietnam, Mekong River Delta and three study areas: Ben Tre, Vinh Long, and Tra Vinh provinces 


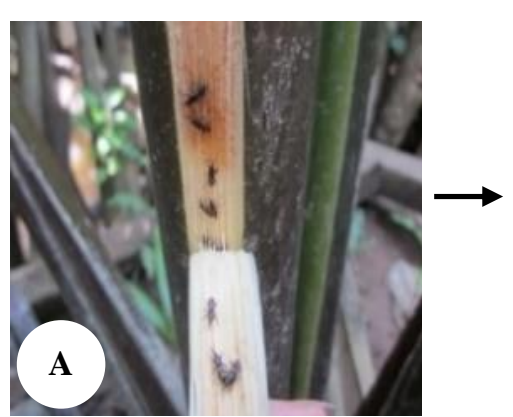

Adult in the field

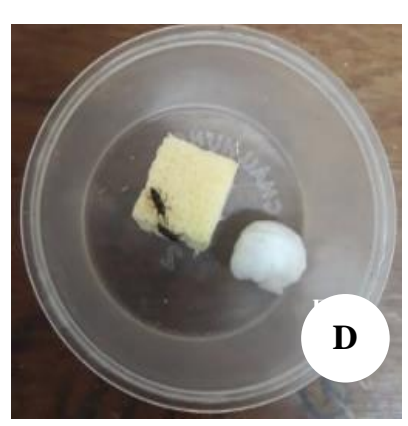

Pairing adults after emergence

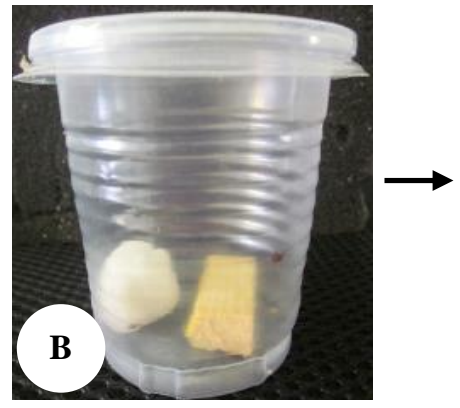

Laying eggs

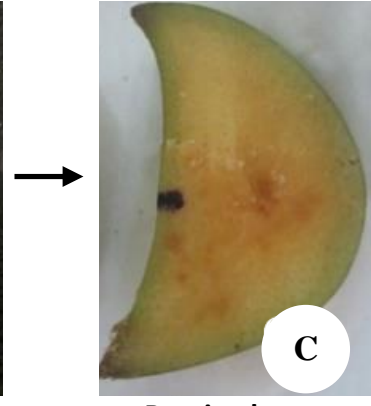

Rearing larvae

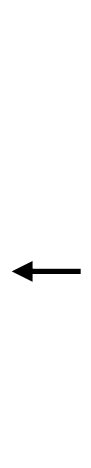

.

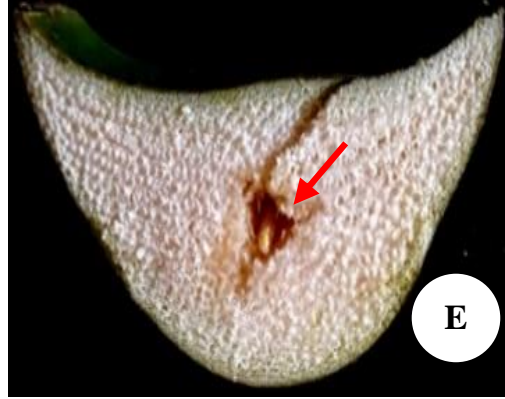

Rearing pupae

Figure 2. Experimental set-up for investigating the morphological and biological characteristics of Diocalandra frumenti: A. Adults in the field, B. Oviposition of eggs, and C-D. Rearing of larvae/pupae to monitor development, and E. Adult pairs to monitor fecundity and longevity

\section{RESULTS AND DISCUSSION}

\section{Attack and damage behavior of Diocalandra frumenti}

Diocalandra frumenti adults laid their eggs scatterly into the tissues (approximately 1.00-2.00 mm) of the young parts of the coconut tree (fruit stalks, sheaths, etc). No eggs were found on the surfaces of the tree. Such information was also found in studies Cuc's (2015) record on coconut orchards in the Mekong Delta. The D. frumenti larvae and pupae were detected under the infected marks and they were also be in the tissues of the coconut trunks, sheaths, flowers, and fruit stalks. (Figure 3). Nguyen Thi Thu Cuc (2015) previously reported that all living processes of $D$. frumenti larvae occurred along their boring lines. The analysis result also indicated that coconut varieties on orchards were not correlated to the damage $(\mathrm{p}>0.05)$.

Diocalandra frumentiadults mainly moved by crawling. They usually sneaked inside the all tree cracks such as trunks, bunches, petioles, fruits and bored through tissue, which then left marks surrounding throughout the fruit stalks. The most noticeable damage was discovered mainly on the fruits and trunks with the characteristic symptom of oozing sap from the infested areas. Once dried, the sap created small blackish-brown holes where the larvae could be found. This insect could damage to both the young and mature fruits, but more common in the young ones. Consequently, it could lead to premature fruit drop or deformity. In addition to the sap oozing phenomenon, damage symptoms of $D$. frumenti also included long, small blackish-brown sunken marks surrounding the young areas of the fruits (Figure 3). These sunken marks, in the long run, would move to the middle of the trunks and fruit apexes and possibly formed big marks on the exocarps. In previous studies, Giblin-Davis (2011) presented that neonate larvae of the lesser coconut weevil bored into tree tissues where the eggs were laid and caused the oozing zap phenomenon, but death of infected coconut trees were not confirmed. EPPO (2012) has declared that the symptoms of this beetle was recorded on the roots, young leaves, sheaths, fruit stalks, and young fruits but it was not found on trunks of host trees. They also concluded that this pest was not only affect on the young fruits, but also on the mature fruits. Report by Vacas et al. (2017) also stated that this species is difficult to recognize with popular symptoms such as emergence holes, fruit fall, gum exudate.

\section{Biological characteristics of $D$. frumenti}

Diocalandra frumenti had four developmental stages: egg, larval, pupal, and adult (Table 1). The life cycle from egg to adult was an average $167 \pm 34.3$ days (mean \pm SD; range: 122 to 271 days) (Figure 4). Compared to the egg stage, the larval stage took significantly longer to complete. In addition, the larvae stage was composed of 19 instars, and duration of each instar development varied greatly, with a gradual increase in development time from 6.21 days (1st instar) to 213 days (1st instar to pupa). Previously, the results were different from Liao and Chen (1997) reported $D$. frumenti larvae, pupae developed in 3540 days and 10-16 days, respectively. The results in this study were also different from Liao and Chen's declaration (1997) in that mature offsprings of $D$. frumenti had a living duration of 15-22 days after emergence. 

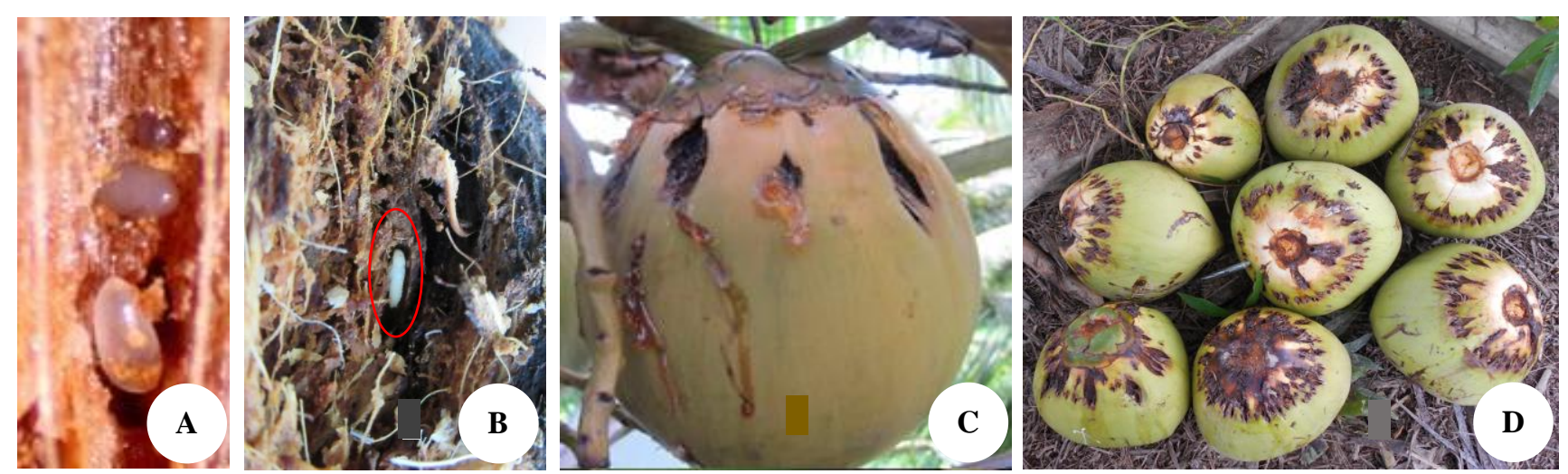

Figure 3.A. Diocalandra frumenti eggs in tree tissue, B. Pupae inside coconut sheaths, and characteristic damage symptoms on coconut: C. Oozing zap phenomenon, and D. Sunken lesions on the fruits

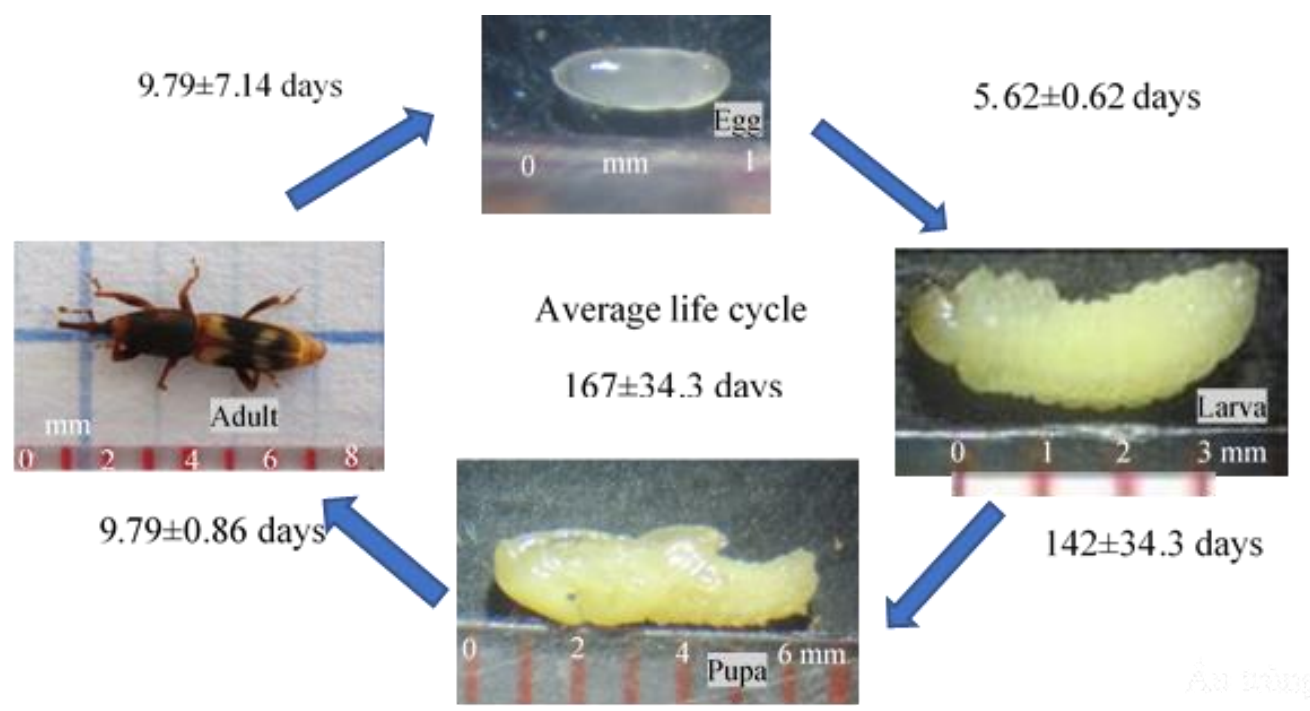

Figure 4. Life cycle of Diocalandra frumenti under the laboratory conditions

Study result on $D$. frumenti life cycle in this study is also different from that of previous reports. Particularly, Liao and Chen (1997) also identified that it lasted about two months. Another record (Cuc 2015) on biological characteristics of this insect showed the development duration from eggs to adults stage takes about in 2-3 months.

This variability in larvae instar development time may be determined by environmental factors (temperature, humidity, and oxygen levels) and nutritional conditions. Temperature affected the development time of immature stages of Ips typographus L. (Coleoptera: Scolytinae), Callipogon relictus Semenov (Coleoptera: Cerambycidae), and Anoplophora glabripennis (Motschulsky) (Coleoptera: Cerambycidae) (Keena and Moore 2010; Štefková et al. 2017; Yi et al. 2019). Li et al. (2015) also reported that the development of Bradysia odoriphaga (Diptera: Sciaridae) at $15^{\circ} \mathrm{C}$ was slower than that at 20,25 , and $30^{\circ} \mathrm{C}$ in the laboratory. In addition, Yang et al. (2014) acknowledged that development time of Bradysia odoriphaga (dependeded on humidity; egg, larvae, preadult development stages of this pest at $50 \% \mathrm{RH}$ were longer than those at 60, 70, and $80 \%$ RH. Heinrich et al. (2011) showed that oxygen concentration was the main factor explaining differences in adult body size of Drosophila melanogaster (Meigen) (Diptera: Drosophilidae) reared under the same conditions. Similarly, the lack of oxygen affected the feeding and molting process of Drosophila melanogaster larvae (Harrison and Haddad 2011). Food quality is also important. Morales-Ramos et al. (2010) showed that different diets markedly changed the development time and the number of instars of Tenebrio molitor L. larvae (Coleoptera: Tenebrionidae); the length of larvae increased steadily at an early stage and slowed from the fifth to the ninth instar. Protein and carbohydrate ratios affected the survival and development of Henosepilachna vigintioctopunctata F. larvae (Coleoptera: Coccinellidae) (Wang et al. 2018). Barraclough et al. (2014) showed that the increase in the number of Pseudocoremia suavis Butler larvae instars was related to poor nutritional conditions, and more larval instars were needed for pupal emergence. Similar findings on the larvae of Orgyia antiqua (L.) (Lepidoptera: Erebidae) were reported by Esperk and Tammaru (2010). 
Table 1. Development time and longevity (mean $\pm 1 \mathrm{SD}, \mathrm{n}=120)$ of Diocalandra frumenti under laboratory conditions $\left(\mathrm{T}=28-31^{\circ} \mathrm{C}\right.$, $\mathrm{RH}=68-80 \%$ ) at Tra Vinh University, Vietnam, from 2016 to 2018.

\begin{tabular}{lll}
\hline \multicolumn{1}{c}{ Development stage } & $\begin{array}{c}\text { Average } \\
\text { duration (days) }\end{array}$ & \multicolumn{1}{c}{$\begin{array}{c}\text { Pupation rate } \\
(\%)\end{array}$} \\
\hline Eggs to $1^{\text {st }}$ instar & $5.62 \pm 0.62$ & - \\
Larvae & $142 \pm 34.3$ & - \\
$1^{\text {st }}$ to $2^{\text {nd }}$ instar & $6.21 \pm 2.11$ & - \\
$1^{\text {st }}$ to $3^{\text {rd }}$ instar & $14.2 \pm 3.69$ & - \\
$1^{\text {st }}$ to $4^{\text {th }}$ instar & $22.6 \pm 5.86$ & - \\
$1^{\text {st }}$ to $5^{\text {th }}$ instar & $29.9 \pm 6.64$ & - \\
$1^{\text {st }}$ to $6^{\text {th }}$ instar & $39.0 \pm 9.04$ & - \\
$1^{\text {st }}$ to $7^{\text {th }}$ instar & $48.4 \pm 11.8$ & - \\
$1^{\text {st }}$ to $8^{\text {th }}$ instar & $58.3 \pm 14.7$ & 9.17 \\
$1^{\text {st }}$ to $9^{\text {th }}$ instar & $70.1 \pm 18.3$ & 16.67 \\
$1^{\text {st }}$ to $10^{\text {th }}$ instar & $76.2 \pm 14.5$ & 15.83 \\
$1^{\text {st }}$ to $11^{\text {th }}$ instar & $87.1 \pm 16.1$ & 20.83 \\
$1^{\text {st }}$ to $12^{\text {th }}$ instar & $96.1 \pm 17.3$ & 4.17 \\
$1^{\text {st }}$ to $13^{\text {th }}$ instar & $109 \pm 19.9$ & 10.00 \\
$1^{\text {st }}$ to $14^{\text {th }}$ instar & $121 \pm 23.6$ & 7.50 \\
$1^{\text {st }}$ to $15^{\text {th }}$ instar & $131 \pm 25.2$ & 5.00 \\
$1^{\text {st }}$ to $16^{\text {th }}$ instar & $138 \pm 20.9$ & 4.17 \\
$1^{\text {st }}$ to $17^{\text {th }}$ instar & $150 \pm 30.2$ & 1.67 \\
$1^{\text {st }}$ to $18^{\text {th }}$ instar & $166 \pm 36.2$ & 1.67 \\
$1^{\text {st }}$ to $19^{\text {th }}$ instar & $185 \pm 42.8$ & 1.67 \\
$1^{\text {st }}$ to pupa & $213 \pm 55.9$ & 1.67 \\
Female pupae & $9.79 \pm 0.86$ & - \\
Male pupae & $10.2 \pm 1.26$ & - \\
Female adult longevity & $81.8 \pm 37.2$ & - \\
Male adult longevity & $81.5 \pm 34.7$ & - \\
\hline
\end{tabular}

As the results, development stage of $D$. frumenti larvae has been proven with huge fluctuations and significantly affected by rearing conditions, of which food compositions were also counted.

The investigation revealed female adults started laying eggs at $02-38$ days after emergence $(9.79 \pm 7.14$ days on average) and finished the egg-laying process at 15-162 days after emergence ( $67.6 \pm 35.2$ days on average). The average life time fecundity was $24.5 \pm 13.8$ eggs per female (range: 02 to 45 eggs).

\section{Morphological characteristics of $D$. frumenti}

Diocalandra frumenti eggs were elongated oval in shape and fairly difficult to locate due to their color and position in the tissue. (Tale 2). Newly laid eggs were transparent white in color. As they aged, the color turned to translucent white, and developed 2 brown-black spots when they were in the pre-hatching period (Figure 5). Giblin and Davis (2011) also recorded D. frumenti eggs were oval with sizes of 0.9 (length) and $0.3 \mathrm{~mm}$ (width). Similarly, in Mekong Delta, this insect eggs were recorded that about $1.0 \mathrm{~mm}$ in length, bright semi-transparent colour (Cuc, 2015).

The first instar larvae were translucent white with brownish-yellow heads. The body color changed to yellow in the later instars. Larvae body and head capsule size also increased gradually until the $19^{\text {th }}$ instar (Table 2, Figures 6 and 7). These were found in Cuc's (2015) record on morphological characteristics of $D$. frumenti. Furthermore, Liao and Chen (1997) also declared that its larvae are white which get the length of approximately 7.00 $\mathrm{mm}$ at full development stage.

Newly emerged $D$. frumenti pupae were translucent white, and turned yellowish as they aged. They developed two black markings on the elytra when close to adult emergence (Figure 8). Liao and Chen (1997) reported that D. frumenti pupae were white, 6.00-7.00 mm long and Cuc (2015) also indicated that this pest was exarate, 5.90-6.30 $\mathrm{mm}$.

Diocalandra frumenti adults had bright-yellowish brown elytra soon after emergence, which turned to blackish brown or yellowish-brown as they aged. They also had four total large yellowish-brown spots on the elytra. The female appeared larger than the male (Table 2). The rostrum of the males was small, short, less curved, and had more setae than that of the females. The males had a yellowish-brown and slightly curved aedeagus, which was $1.00 \mathrm{~mm}$ long.

Diocalandra frumenti adults had four basic morphologies:1) black elytra, four total yellow spots on elytra, black head; 2) blackish-brown elytra, four total yellow spots on elytra, brown or yellowish-brown head; 3) brown or blackish-brown elytra, four total invisible spots on elytra, like a bright yellow stripe, yellow or brown head; and 4) brown or blackish-brown elytra, four total visible yellow spots, and numerous big bright yellow spots on head (Figure 9).
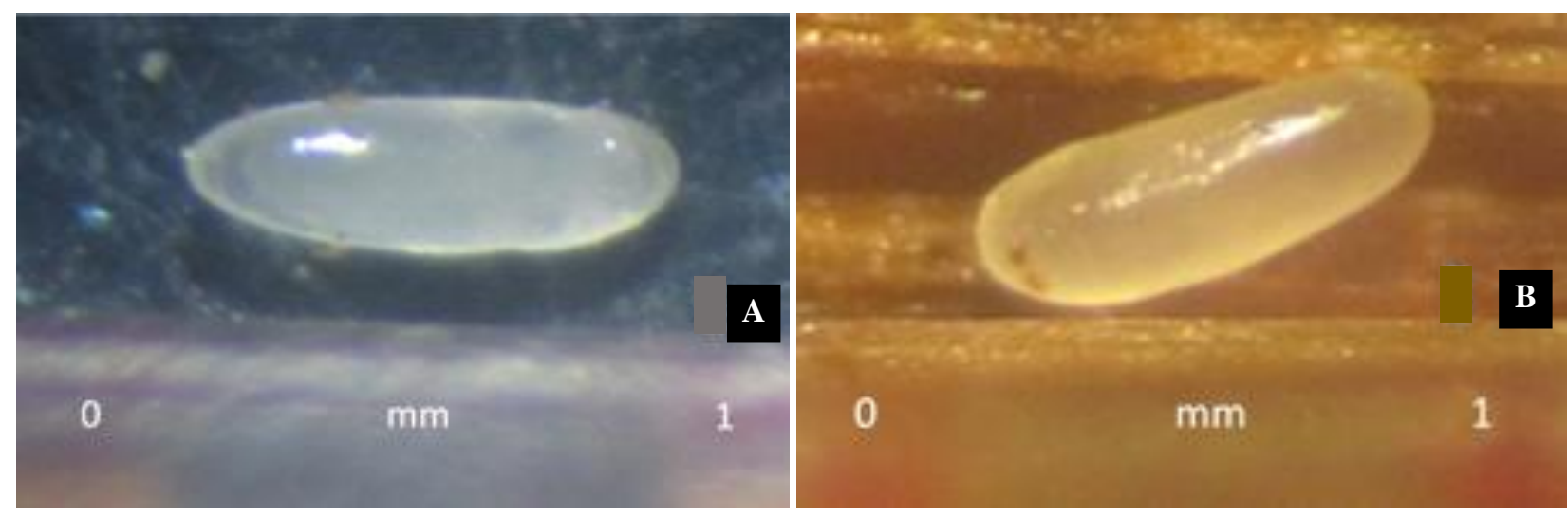

Figure 5. A. Diocalandra frumenti eggs: newly laid, and B. Pre-hatching 

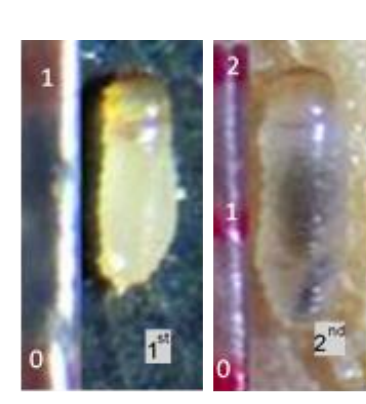

NGUYEN et al. - Biology, morphology and damage of Diocalandra frumenti

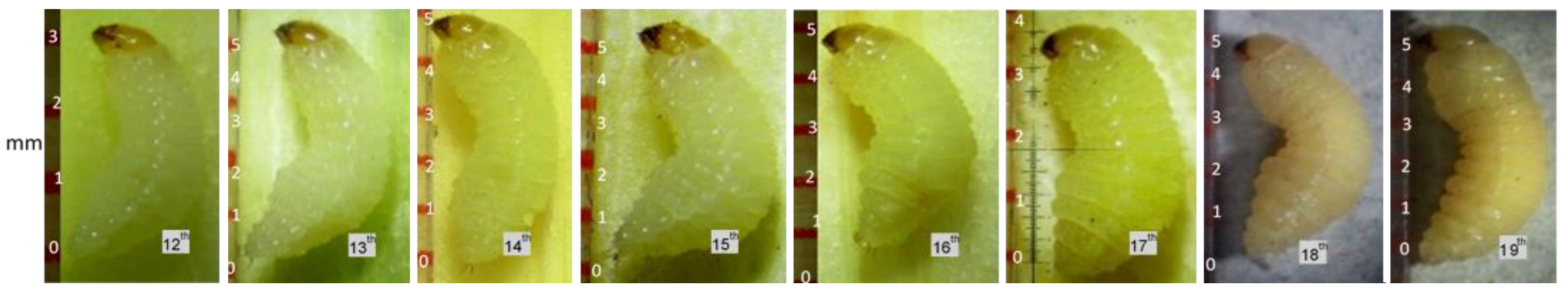

Figure 6. Morphological characteristics of Diocalandra frumenti larvae from the $1^{\text {st }}-19^{\text {th }}$ instar $(\mathrm{mm})$
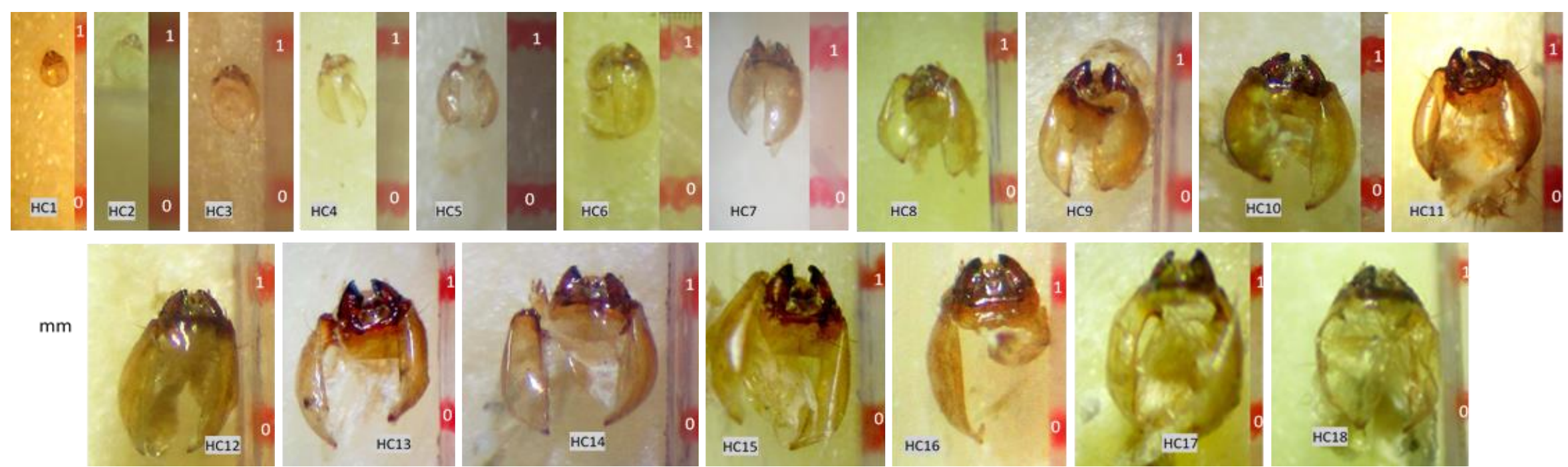

Figure 7. Head capsules (HC) of Diocalandra frumenti larvae from the $1^{\text {st }}-18^{\text {th }}$ instar (mm) 

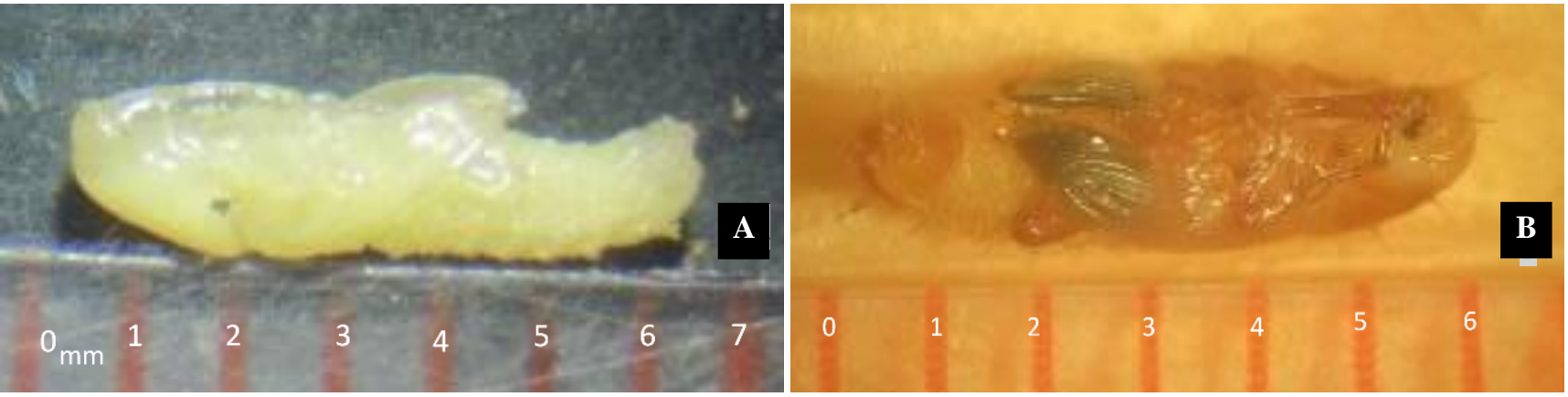

Figure 8. A. Pupae of Diocalandra frumenti soon after pupal emergence, and B. Close to adult emergence
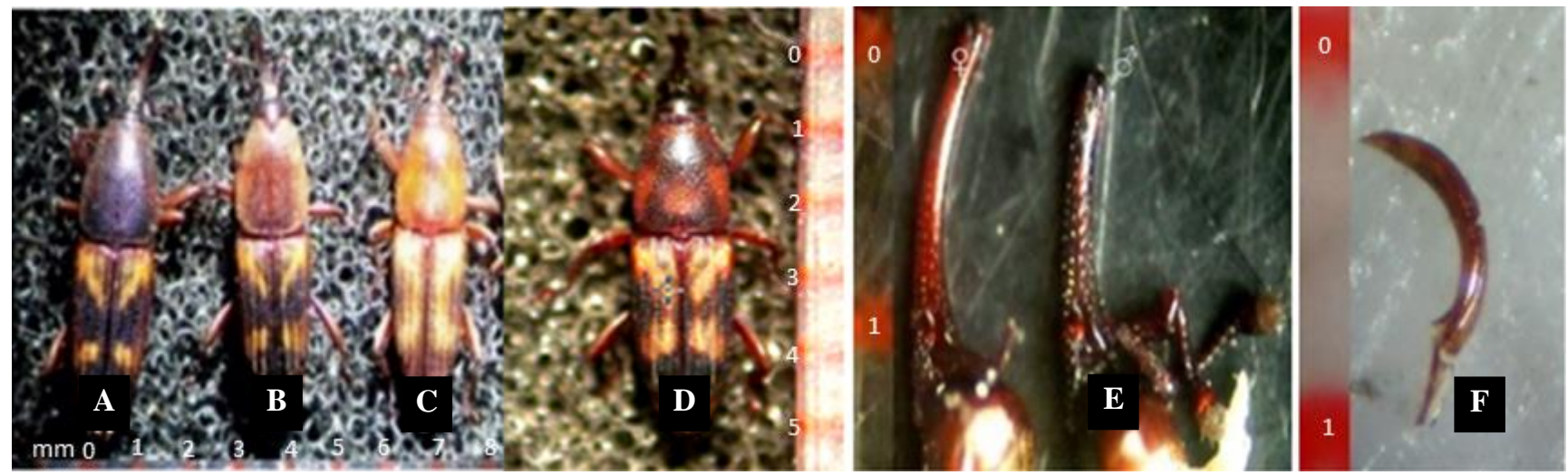

Figure 9. A-D. Diocalandra frumenti adults: four morphologies, E. Rostrum of male and female adults, and F. Aedeagus of male adults

Table 2. Size (mean $\pm 1 \mathrm{SD}, \mathrm{n}=120)$ of Diocalandra frumenti larvae reared under laboratory conditions $\left(\mathrm{T}=28-31^{\circ} \mathrm{C}, \mathrm{RH}=68-80 \%\right)$ of Tra Vinh University, Vietnam, from 2016-2018

\begin{tabular}{|c|c|c|c|c|c|}
\hline \multirow{2}{*}{ Development stage } & \multirow{2}{*}{ Samples } & \multicolumn{4}{|c|}{ Average sizes (mm) } \\
\hline & & Head capsule length & Head capsule width & Body length & Body width \\
\hline Eggs & & & - & $0.85 \pm 0.07$ & $0.29 \pm 0.04$ \\
\hline $1^{\text {st }}$ Instar & 120 & $0.22 \pm 0.05$ & $0.18 \pm 0.04$ & $1.15 \pm 0.11$ & $0.24 \pm 0.05$ \\
\hline $2^{\text {nd }}$ Instar & 120 & $0.29 \pm 0.04$ & $0.27 \pm 0.05$ & $1.61 \pm 0.23$ & $0.30 \pm 0.03$ \\
\hline $3^{\text {rd }}$ Instar & 120 & $0.41 \pm 0.04$ & $0.33 \pm 0.05$ & $2.38 \pm 0.63$ & $0.40 \pm 0.07$ \\
\hline $4^{\text {th }}$ Instar & 120 & $0.51 \pm 0.07$ & $0.42 \pm 0.08$ & $2.99 \pm 0.66$ & $0.49 \pm 0.08$ \\
\hline $5^{\text {th }}$ Instar & 120 & $0.59 \pm 0.88$ & $0.53 \pm 0.11$ & $3.66 \pm 0.87$ & $0.55 \pm 0.06$ \\
\hline $6^{\text {th }}$ Instar & 120 & $0.71 \pm 0.10$ & $0.61 \pm 0.11$ & $4.18 \pm 0.97$ & $0.65 \pm 0.11$ \\
\hline $7^{\text {th }}$ Instar & 120 & $0.82 \pm 0.10$ & $0.75 \pm 0.12$ & $4.82 \pm 0.83$ & $0.78 \pm 0.12$ \\
\hline $8^{\text {th }}$ Instar & 109 & $0.91 \pm 0.11$ & $0.81 \pm 0.11$ & $5.28 \pm 0.69$ & $0.88 \pm 0.11$ \\
\hline $9^{\text {th }}$ Instar & 89 & $0.96 \pm 0.09$ & $0.85 \pm 0.11$ & $5.43 \pm 0.70$ & $0.96 \pm 0.12$ \\
\hline $10^{\text {th }}$ Instar & 70 & $0.98 \pm 0.10$ & $0.88 \pm 0.11$ & $5.80 \pm 0.67$ & $1.03 \pm 0.12$ \\
\hline $11^{\text {th }}$ Instar & 45 & $1.03 \pm 0.11$ & $0.92 \pm 0.11$ & $5.96 \pm 0.60$ & $1.09 \pm 0.13$ \\
\hline $12^{\text {th }}$ Instar & 40 & $1.07 \pm 0.08$ & $0.97 \pm 0.09$ & $6.08 \pm 0.53$ & $1.15 \pm 0.10$ \\
\hline $13^{\text {th }}$ Instar & 28 & $1.08 \pm 0.07$ & $0.98 \pm 0.07$ & $6.03 \pm 0.39$ & $1.15 \pm 0.08$ \\
\hline $14^{\text {th }}$ Instar & 19 & $1.09 \pm 0.06$ & $0.99 \pm 0.06$ & $6.03 \pm 0.40$ & $1.18 \pm 0.06$ \\
\hline $15^{\text {th }}$ Instar & 13 & $1.12 \pm 0.06$ & $1.02 \pm 0.06$ & $5.99 \pm 0.40$ & $1.19 \pm 0.05$ \\
\hline $16^{\text {th }}$ Instar & 8 & $1.14 \pm 0.08$ & $1.03 \pm 0.08$ & $6.09 \pm 0.50$ & $1.21 \pm 0.07$ \\
\hline $17^{\text {th }}$ Instar & 6 & $1.16 \pm 0.09$ & $1.08 \pm 0.04$ & $5.94 \pm 0.54$ & $1.26 \pm 0.05$ \\
\hline $18^{\text {th }}$ Instar & 4 & $1.20 \pm 0.00$ & $1.10 \pm 0.00$ & $5.85 \pm 0.57$ & $1.33 \pm 0.05$ \\
\hline $19^{\text {th }}$ Instar & 2 & $1.20 \pm 0.00$ & $1.10 \pm 0.00$ & $5.60 \pm 0.85$ & $1.35 \pm 0.07$ \\
\hline Female pupae & 63 & - & - & $5.22 \pm 0.35$ & $1.16 \pm 0.06$ \\
\hline Male pupae & 57 & - & - & $5.15 \pm 0.32$ & $1.11 \pm 0.06$ \\
\hline Female adults & 63 & - & - & $6.23 \pm 0.44$ & $1.17 \pm 0.15$ \\
\hline Male adults & 57 & - & - & $5.14 \pm 0.42$ & $1.08 \pm 0.09$ \\
\hline
\end{tabular}


Table 3. Damage of Diocalandra fumenti in coconut orchards in the Tra Vinh, Vinh Long and Ben Tre provinces, Vietnam, in 2015

\begin{tabular}{|c|c|c|c|c|}
\hline \multirow[b]{2}{*}{ Locations } & \multicolumn{4}{|c|}{ Average damage (\%) } \\
\hline & $\begin{array}{l}\text { Damaged } \\
\text { orchards }\end{array}$ & $\begin{array}{l}\text { Damaged trees/ orchards } \\
(n=270)\end{array}$ & $\begin{array}{l}\text { Damaged bunches/orchards } \\
(n=9,141)\end{array}$ & $\begin{array}{l}\text { Damaged fruits/orchards } \\
(\mathrm{n}=39,975)\end{array}$ \\
\hline Tra Vinh Province & 100 & $56.1 \pm 24.9$ & $17.6 \pm 11.5$ & $8.00 \pm 6.53$ \\
\hline Vinh Long Province & 100 & $65.2 \pm 18.9$ & $18.5 \pm 9.10$ & $6.91 \pm 4.07$ \\
\hline Ben Tre Province & 100 & $55.3 \pm 31.4$ & $22.1 \pm 17.5$ & $8.40 \pm 5.47$ \\
\hline Average ratios & 100 & $58.9 \pm 25.5$ & $19.4 \pm 12.9$ & $7.77 \pm 5.46$ \\
\hline
\end{tabular}

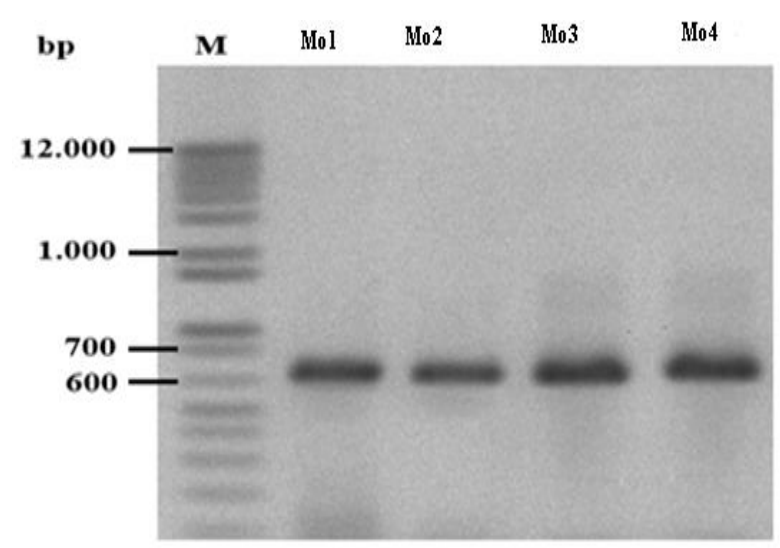

Figure 10. PCR Electrophoresis results of Diocalandra frumenti specimens on gel agarose $(\mathrm{Mo}=$ morphology)

The electrophoresis results indicated that the collected amplification primers of COI gene sequences showed only one line with a size of 648 bp containing typical sequences for insect nomenclature (Figure 10). In the different studies, Ung (2019) indicated that the high similarity of the gene sequence proved the morphologies of lesser coconut weevil collected in the 12 provinces belong to the $D$. frumenti species and had the same inheritance. Besides, Ung (2019) previously reported that all four $D$. frumenti morphologies collected in the Mekong Delta and Southeast region (Vietnam) had the same genotypes. Investigations with ISSR molecular markers revealed that 40 specimens of the $D$. frumenti popula-tions were divided into four main groups based on the genetic linkage map with the genetic distances fluctuating from 3.16 to 8.54 (Ung 2019).

Previosuly, Barbosa et al. (2014) used CI-J-2183 and TL2-N-3014 primers for COI gene sequencing application to Chrysoperla externa, and the results were similar as those of the amplified gene sequences with the size of 648 bp. A DNA barcode to determine and differentiate between animal species can be carried out via a $648 \mathrm{bp}$ fragment of COI (Karthika et al. 2016). Arun and Ramesha (2017) also demonstrated that D.frumemti adults with different colors were the same species and the difference in color of adults may be due to the influence of food and habitat.

\section{Diocalandra frumenti on coconut orchards collected from farmer interviews}

In general, average percentages of households who recognized damages caused $D$. frumenti in the Mekong Delta in 2013 and 2014 was $32.9 \%$ and $41.6 \%$, respectively. Farmers in Ben Tre province mainly realized its damage in $2013(30.7 \%)$ and those in the other two provinces (58.9\% for Tra Vinh and $43.3 \%$ for Vinh Long) knew about it in 2014. When presented at the level of fruits, most farmers revealed the percentage of infested fruits was about 5\% (38.4\% households) and about 10-30\% ( $27.5 \%$ households) in 2014 and 2015, respectively. In addition, the percentages of famers confirmed that this insect affected only coconut fruits, and it occurred throughout the year $(43.9 \%)$, in the dry season $(29.0 \%)$, in the rainy season $(14.9 \%)$. Weevil infestation was recorded at $24.7 \%$ in coconut fruits irrespective of maturity stage, with $57.6 \%$ in immature and $8.24 \%$ in mature fruits, respectively. Moreover, the majority of the farmers $(62.9 \%)$ could not find effective methods to control $D$. frumenti, whereas the rest farmers (37.1\%) used commercial chemicals to kill it. Although EPPO (2012) and Cuc (2015) also recorded that D. frumenti can damage on several parts of the coconut tree, the farmers only recognized $D$. frumenti symptoms on the coconut fruits. According to Ung (2019), this can be explained by some reasons. Of which, D. frumenti is a new pest so the farmer did not fully understand the harmful symptoms of this species. Besides, the coconut fruits are the main harvest product so the farmer only notices the damage on this part on their orchards.

\section{The damage levels of Diocalandra frumenti according to investigations on coconut orchards.}

There was no extreme variation among these provinces in the percentage of the damaged coconut trees, damaged coconut bunches, and damaged coconut fruits per orchard (Table 3). Although more than half of the trees per orchard were infested, less than $10 \%$ of the coconut fruits per orchard were infested. According to Liao and Chen (1997) and Giblin-Davis (2011), if heavily infested, D. frumenti can kill whole coconut trees. So, although the coconut fruit is the main part of the harvest, the $D$. frumenti infestation on other part also can decrease of the coconut trees yield (Ung, 2019). 
In conclusion, $D$. frumenti herbivory results in serious damage to coconut trees, coconut bunches, and fruits throughout the year. The morphological and biological characteristics of this pest varied widely in terms of development time, shape, color, and size of the eggs, larvae, pupae, and adults. Further studies are necessary to develop an effective technique that can control and reduce damage by this insect.

\section{REFERENCES}

Arun KS, Ramesha B. 2017. Taxonomic redescription of the coconut bark weevil (Diocalandra frumenti). J Pharmacogn Phytochem SP1: 10491053.

Barbosa NCC, Freitas SD, Morales AC. 2014. Distinct genetic structure in populations of Chrysoperla externa (Hagen) (Neuroptera, Chrysopidae) shown by genetic markers ISSR and COI gene. Rev. Bras. Entomol 58 (2): 203-211.

Barraclough EI, Burgess EPJ, Kean AM, Malone LA. 2014. Growth and development in a lepidopteran with variable instar number, Pseudocoremia suavis (Geometridae), under standard rearing conditions and when parasitised by Meteorus pulchricornis (Hymenoptera: Braconidae). Eur J Entomol 111 (4): 1-11.

Cuc NTT. 2015. Insect, mite pests of fruit trees in Vietnam and their natural enemies. Can Tho University Publishing House, Vietnam.

EPPO. 2012. EPPO Technical Document No. 1061, EPPO Study on the Risk of Imports of Plants for Planting. Paris.

Esperk T, Tammaru T. 2010. Size compensation in moth larvae: attention to larval instars. Physiol. Entomol 35: 222-230.

Giblin-Davis RM. 2011. Borers of palms. In: Howard, FW, Moore D, Giblin-Davis RM, Abad RG (Eds) Insects on Palms. CABI Publishing, UK.

Given BB. 2012. List of insects collected on niue island during February and March, 1959. NZ Entomol 4 (1): 40-42.

Grunert LW, Clarke JW, Ahuja C, Eswaran H, Nijhout HF. 2015. A Quantitative analysis of growth and size regulation in Manduca sexta: The physiological basis of variation in size and age at metamorphosis. $\begin{array}{llll}\text { PLoS ONE } & 10 & \text { (5): } & \text { e0127988. }\end{array}$ https://doi.org/10.1371/journal.pone.0127988

Gunn BF, Baudouin L, Olsen KM. 2011. Independent origins of cultivated coconut (Cocos nucifera L.) in the old world tropics. PLOS ONE 6 (6): e21143.

Harrison JF, Haddad GG. 2011. Effects of oxygen on growth and size: synthesis of molecular, organismal and evolutionary studies with Drosophila melanogaster. Annu Rev Physiol 73: 95-113
Heinrich EC, Farzin M, Klok CJ, Harrison JF, 2011. The effect of developmental stage on the sensitivity of cell and body size to hypoxia in Drosophila melanogaster. Exp Biol 214 (9): 1419-1427.

Keena MA, Moore PM. 2010. Effects of temperature on Anoplophora glabripennis (Coleoptera: Cerambycidae) larvae and pupae. Environ Entomol 39 (4): 1323-1335.

Karthika P, Krishnaveni N, Vadivalagan C, Murugan K, Nicoletti M, Benelli G. 2016. DNA barcoding and evolutionary lineage of 15 insect pests of horticultural crops in South India. Karbala International Journal of Modern Science 2: 156-168

Li W, Yang Y, Xie W, Wu Q. 2015. Effects of temperature on the agestage, two-sex life table of Bradysia odoriphaga (Diptera: Sciaridae). Econ Entomol 108 (1):126-134.

Liao CT, Chen CC. 1997. Primary study the insect pests, hosts and ecology of weevil attacking ornamental palm seedlings. Bull Taichung Dist Agric Improv Stn 57: 43-48.

Manisha DM, Mandal S. 2011. Coconut (Cocos nucifera L.: Arecaceae): In health promotion and disease prevention. Asian Pac J Trop Med 4 (3):241-247

Morales-Ramos JA, Rojas MG, Shapiro-Ilan DI, Tedders WL. 2010. Developmental plasticity in Tenebrio molitor (Coleoptera: Tenebrionidae): analysis of instar variation in number and development time under different diets. Entomol SCI 45 (2):75-90.

Štefková K, Okrouhlik J, Dolezal P. 2017. Development and survival of the spruce bark beetle, Ips typographus (Coleoptera: Curculionidae: Scolytinae) at low temperatures in the laboratory and the field. Eur J Entomol 114: 1-6.

Ung NH. 2019. Study on Biological Characteristics and Control Methods on Lesser Coconut Weevil Diocalandra frumenti Fabricius (Coleoptera: Curculionidae) in the Mekong Delta. [Dissertation]. Can Tho University, Vietnam. [Vietnam].

Vacas S, Navarro I, Seris E, Ramos C, Hernández E, Navarro-Llopis V, Primo J. 2017. Identification of the male-produced aggregation pheromone of the Four-spotted Coconut weevil, Diocalandra frumenti. Agr Food Chem 65 (2): 270-275

Wang ZL, Wang XP, Li CR, Xia ZZ. 2018. Effect of dietary protein and carbohydrates on survival and growth in larvae of the Henosepilachna vigintioctopunctata (F.) (Coleoptera: Coccinellidae). Insect Sci 18 (4): $3 ; 1-7$

Wibowo A, Sloterdijkb H, Ulrichb SP. 2015. Identifying Sumatran peat swamp fish larvae through dna barcoding, evidence of complete life history pattern. Procedia Chem 14: 76-84.

Yang Y, Li W, Xie W, Wu Q, Wang S, Li C, Zhang Y. 2014 Development of Bradysia odoriphaga (Diptera: Sciaridae) as affected by humidity: an age-stage, two-sex, life-table study. Appl Entomol Zool 50: 3-10.

Yi DA, Kuprin AV, Bae YJ. 2019. Effects of temperature on instar number and larval development in the endangered longhorn beetle Callipogon relictus (Coleoptera: Cerambycidae) raised on an artificial diet. Can Entomol: 1-8. 